\section{UNIVERSITY \\ OF DEBRECEN}

FACULTY OF

HEALTH

NYÍREGYHÁZA

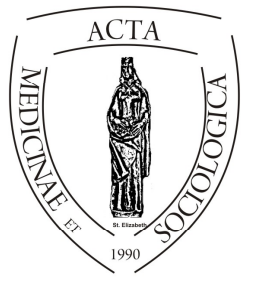

ACTA

MedSoc

VOLUME 5.

2014

\title{
A vezetési stílus, a változási készség és a konfliktus kezelés vizsgálata egy magyar- országi Multinacionális vállalatnál
}

\author{
Sipos Gábor - Szücs Edit - Takács Tímea - Matkó Andrea \\ Debreceni Egyetem Müszaki Kar Müszaki Menedzsment \\ és Vállalkozási Tanszék
}

\begin{abstract}
The study purpose to examine what leadership style is used by a successful Hungarian multinational company for the efficient and effective working. In addition the corporate leaders how to respond for the adaptation challenge caused by changes in the external environment, meaning what the change skills. Conflict is a common phenomenon in organizations because of intense competition. Conflict management is a major test of the best professionals. Our research purpose of to examine leadership style, change skills and conflict management in the company. We set several goals in our research and we used descriptive statistics.
\end{abstract}

Keywords: Harsey-Blanchard model, leaders, leadership styles, conflict management, change skill

DOI: $10.19055 / \mathrm{ams} .2014 .5 / 14-15 / 6$ 


\section{BEVEZETÉS}

A szervezetek vezetésének tudománya egyre nagyobb jelentőséggel bír, és egyre jobban felértékelődik korunkban. Ennek több oka is van. Az egyik a gazdasághoz köthetö, mely szerint a vezetés kulcsfontosságú szerepe abban nyilvánul meg, hogy növelje a termelékenységet az erőforrások optimális összehangolásával, és ez által kielégítse a társadalom anyagi szükségleteit. A másik ok társadalmi eredetü. A vezetés formálja az egy csoportban, egy közös célért dolgozó emberek társadalmi kapcsolatait, ezáltal közösségi szellemüket és tudásukat is fejleszti. A harmadik ok pedig a vállalatokkal kapcsolatos. A szervezetek célja napjainkban a minél nagyobb profit szerzése, a hatékonyság növelése, a piacon való stabil elhelyezkedés és természetesen a fennmaradás. Mindezekhez elengedhetetlen a vállalat összes funkciójának eredményes müködése. A szerepekkel pedig szervesen összekapcsolódik a vezetés, minden funkcióban jelentőséggel bír, és egyiktől sem választható külön.

A vezető tevékenysége sokrétü, felelősséggel tartozik a szervezet sikeres müködéséért. Emellett személyes példamutató szerepet tölt be alkalmazottai és a külvilág felé. A külső körülményekhez való alkalmazkodás gyorsaságában a vezetők fontos szerepet játszanak. Megfogalmazzák a vállalat jövőképét, értékeket, és irányelveket határoznak meg a szervezetben dolgozóknak. A célok és célkitüzések képessé teszik a szervezetet a rövid és hosszú távú eredmények eléréséhez.

Kutatásunkat egy debreceni, nagy múltra visszatekintő multinacionális vállalatnál végeztük. A vállalat életében a hosszú és rövid távú célkitüzések a vezetés részéről meghatározóak, illetve maga a vezetés is szerves részét képezi a vállalat sikerességének. Kutatásunk során megvizsgáltuk a vállalat esetében a vezetési stílust, a változási készséget és a konfliktuskezelést. Azért fokuszáltunk erre a három területre, mert a kialakult gazdasági helyzet és a gyorsan változó környezeti feltételek számos kihívást támasztanak a vezetőkkel szemben. Ennek ellenére a cég folyamatosan növekvő tendenciát mutat, melynek eléréséhez és fenntartásához szükséges a megfelelö vezetés és a különböző változásokra való készség. A 2008-as gazdasági válságban a gyár közel 50\%-os termeléscsökkenés ellenére felismerte, hogy a jövő kihívásaira megfelelően fel kell készülni, ezért a tartalékait, melyek a termeléskiesésből adódtak folyamatjavításra és optimalizálásra használták fel. A változások következtében felmerülö konfliktusok, változási hajlandóság megfelelö és hatékony kezelése tette a vizsgált szervezetet egy folyamatosan növekvő, fejlődő sikerorientált vállalattá.

Kutatásunk célja, hogy a vállalaton belül definiált három vezetői szint vezetési stílusát, változási készségét és konfliktuskezelési módját megvizsgáljuk. 


\section{LEADERSHIP}

A leadership rendkívül sokrétü és összetett fogalom, mely a szervezet magatartásával foglalkozik. A szakirodalom szerint nem egyértelmü, hogy a vezetői magatartásról, a vezetői stílusról, a vezetői szerepről vagy a vezetői funkciókról beszélünk. Minden megközelítés helytálló, de egy megközelítés sem léphet fel a teljes értelmezés igényével. A nemzetközi irodalomban fellelhető fogalmi és definíciós vita mellé a magyar nyelv fordításbeli nehézségek miatt többféle értelmezés társul. A legtöbb leadership definíció a következő föbb elemeket hangsúlyozza: a befolyásolás, a csoport és a cél. Bakacsi (2004:184) definíciója alapján: „a leadership a vezetői tevékenység egy olyan eleme, amely a szervezeti erőforrások közül kitüntetetten az emberi erőforrással foglalkozik (a vezető és beosztottai közötti kapcsolat módjára keresi a választ)." Annak képességét jelenti, hogy hogyan tudja a vezető a szervezet tagjait a szervezeti célok megvalósítására befolyásolni, mozgósítani (Karácsonyi, 2006).

\subsection{LEADERSHIP ELMÉLETEK}

A leadership elméletek sajátossága abban rejlik, hogy egy vezető hogyan tudja a saját alkalmazottainak értékeit, szükségleteit felismerni, összekapcsolni és hatékonyan mozgósítani. Az alkalmazott vezetési stílus több tényezőtől függ: a vezető személyiségétől, a beosztottak és a szervezet, a környezet viselkedésétől, a vezetőtől, a csoporttól, a szervezet céljaitól és szükségleteitől.

\section{Hersey és Blanchard kontingencialista elmélete}

A sikeresség alapja a vezető tudatos erőfeszítése, illetve a változó helyzetekhez való alkalmazkodási képesség mozgósításnak képessége, vagyis a vezető tartja kezében a problémákra a megoldás kulcsát, abban a tekintetben, hogy mennyire képes az adott helyzet, szituáció felmérésére, diagnosztizálására és a kialakult helyzethez / helyzetekhez hogyan tudja igazítani a stílusát, viselkedését. A vezetés akkor hatékony, ha minden szempontból megfelel annak a szituációnak, amelyben alkalmazni kell (Bakacsi, 2004).

A helyzethez igazított vezetés alapelemei:

- feladatra figyelés

- kapcsolatra figyelés

- a munkatárs és a feladat jellemzői

- a vezető igényei (FN24, 2011). 
Az egyes stílusokhoz jellemző vezetői viselkedéseket Hersey és Blanchard fogalmazták meg (Ford, 1995). Elméletük szerint a vezetöknek váltogatni kell az egyes vezetői stílusok között, azonban a vezető stílusát meghatározza a beosztottak érettsége. A beosztottak értettségének növekedésével a kapcsolatorientált stílusok eredményesebbek. Az érettség egy adott szintje felett engedni kell, hogy a beosztottak akarata érvényesüljön. Ezért a modell független változója a követők személyiségének érettsége. A modell szerint négy egymástól jól elkülöníthető vezetői stílust különböztetünk meg (1. ábra).

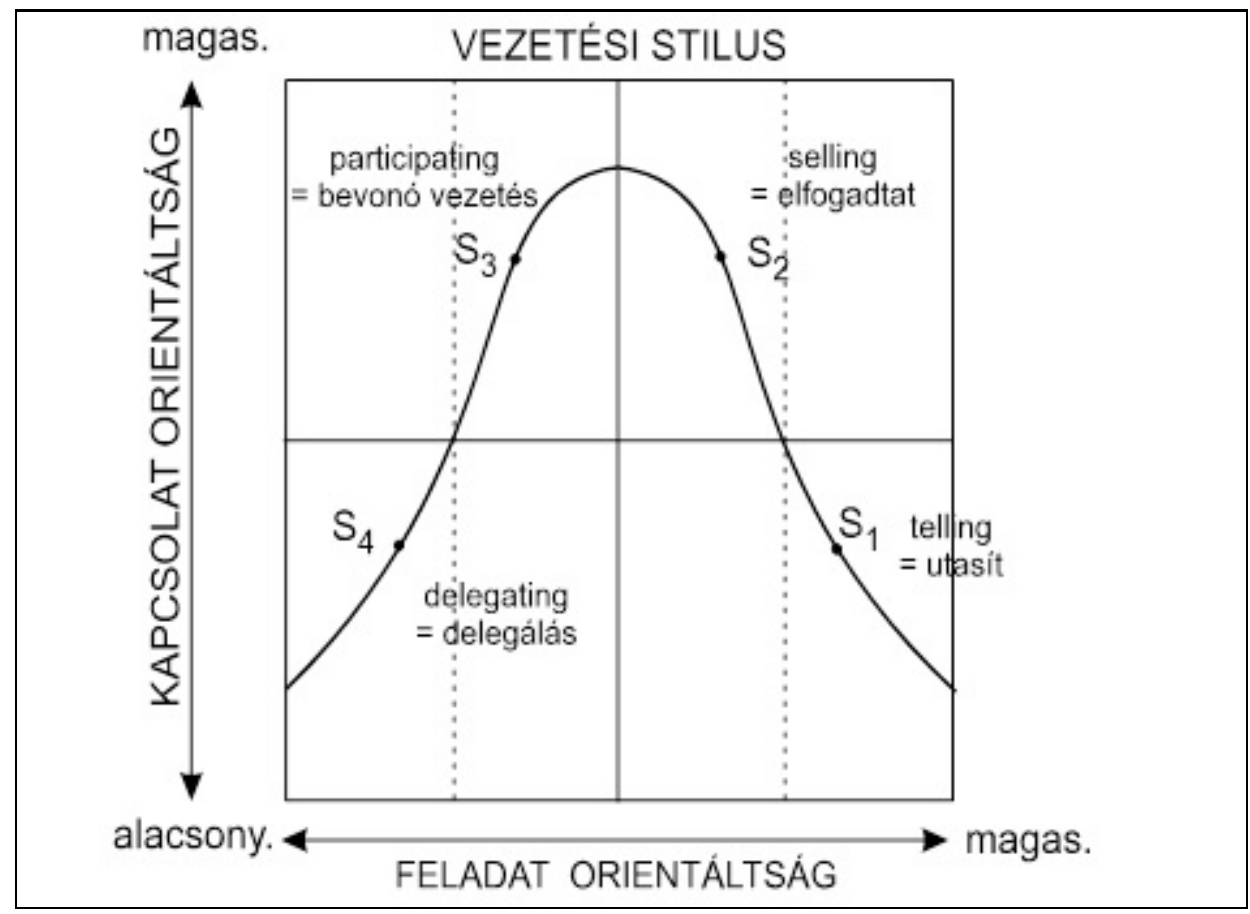

1. ábra: Hersey és Blanchar szituációs modellje (Forrás: Gyökér, 2006:15)

Az ábra alapján láthatjuk, hogy Hersey és Blanchar négy vezetöi típust különít el a kapcsolat orientáltságának szintje szerint, modelljük a feladat- és a kapcsolatorientált magatartásokat tükrözi.

S1. Utasitó vezetés: Erős feladat-, gyenge kapcsolatorientáltság jellemzi a vezetőt. A vezető tudja mit akar, és világosan el is mondja a beosztottainak. Világos 
egyértelmü utasítások jellemzik, erős szabályozó és ellenőrző funkció. Gyakran például erre van szükség az újonnan belépő dolgozók esetében.

S2. Elfogadtató vezetés (Coaching): Erős feladat- és kapcsolatorientáltság jellemzi a vezetőt. A vezető részletesen elmagyarázza a teendőket. Kétirányú kommunikációra és motivációra épülve igyekszik bizalmat ébreszteni a dolgozókban, de a döntések felelősségét, az ellenőrzést a vezető nem adja ki a kezei közül. A humánus hozzáállás, a csoportmunka, a szabványok tudatosítása a munkacsoport szempontjainak mérlegelése és a folyamatok szabályozása jellemzi ezt a vezetői stílust. Ez a stílus a leginkább még nem tapasztalt kezdő dolgozók számára a megfelelö.

S3. Bevonó vezetés (szupportiv): Gyenge feladat-, erős kapcsolatorientáltság jellemzi a vezetőt. Ezen stílus esetén a vezető és a csapat együtt dönt. A vezető ebben az esetben azon van, hogy a munkába és a döntéshozatalba mindenki be legyen vonva és a munkatársak támogatva érezzék magukat.

S4. Delegáló vezetés: Gyenge feladat- és kapcsolatorientáltság jellemzi a vezetőt. A vezető önállóságot ad a beosztottainak. Célokat a munkatársak határozzák meg és a problémákat szintén ők oldják meg és mindezt a vezető egyfajta támogatásával teszik (Ford, 1995).

A vezetési stílus mellett nagyon fontos, hogy a vezető milyen változási készséggel rendelkezik, mert a vállalat sikeressége és hatékonysága függ a vezető reagálási gyorsaságától és alkalmazkodási készségétől.

\section{VÁLTOZÁSI KÉSZSÉG}

Napjainkban a dinamikusan változó gazdasági környezet, a kiélezett versenyhelyzet következtében elengedhetetlen a folyamatos változás, amelyre a vezetőknek állandóan reagálnia kell. Megkülönböztetünk tervszerú és váratlan, külső hatásokra létrejövő változást. A tervszerü szervezeti változásoknak fő célja a vállalat, a vállalkozás alkalmazkodó-képességének fejlesztése, míg a váratlan hatásokra létrejövő változás célja a kedvezötlen hatások kiküszöbölése. A vezetésnek nemcsak a hagyományos vezetői feladatokkal kell megbirkóznia, hanem a változások folyamatos menedzselésével is. A változtatás kezdeményezése egy szervezeten belül nagyon fontos elhatározás. Bevezetése minden esetben kivált kisebb-nagyobb ellenállást a szervezeten belül, melynek fő oka a bizonytalanság. $\mathrm{Az}$ emberek gyakran bizonytalanok a változás hatását illetően. Ezért a mene- 
dzser első lépése a problématerület feltérképezése, körülhatárolása, illetve a probléma típusának tisztázása. Ehhez különböző felméréseket kell végezni. A felmérésekkel és a megismerési modellek alkalmazásával a menedzser eljut a valódi probléma felismeréséhez, és a probléma jellegének, típusának tisztázásához (Vezetés nincs szerző?, 2009).

A változtatási folyamat elsö fázisa a diagnóziskészítés, amely a rendszer leírásával (modellezésével) kezdődik. A rendszer a teljes érintett körnek a bevonásával történik. Ebben a fázisban fontos, hogy a rendszer leírása közben közvetlen kontaktus legyen a „problémagazdákkal”, azaz a tényleges döntéshozókkal. A folyamatot addig kell folytatni, amíg ki nem alakul a konszenzus a résztvevők között.

A második fázis a célok és a korlátok rögzítésével folytatódik. Tisztázni kell a változással elérni kívánt célokat, továbbá azokat a korlátokat, amelyek között a változás reálisan megvalósítható. A célok és korlátok leírása a rendszerleíráshoz hasonlóan egy interaktív folyamat. Ebben a fázisban természetesen megfogalmazódhatnak olyan célok is, amelyek nyíltan vagy burkoltan azt sugallhatják, hogy a változásra semmi szükség nincs.

A harmadik fázis a változtatás stratégiájának kialakítása. Ha a probléma tisztázódott és az okok ismertté váltak, akkor ki kell alakítani a változtatás alapvető stratégiáját. A stratégia részvételen alapuló döntés-előkészítési folyamatában arra kell különös figyelmet fordítani, hogy kiderüljön, mit akarnak a résztvevők. Arra kell törekedni, hogy a zavaros helyzetek határvonalai egyértelmủek legyenek, ezzel sok későbbi meddő vita megelőzhető. A zavaros helyzet úgy tehető kezelhetővé, áttekinthetővé, hogy a legfontosabb külső és belső kapcsolatok azonosításával meg kell próbálni a struktúrát felvázolni és megérteni. Azt is el kell érni, hogy a célokban és a korlátokban azonos értelmezés jöjjön létre az együtt dolgozók körében.

A negyedik fázis a változtatások részletes akcióterveinek elkészítése. Ebben a szakaszban kerül sor a változtatást elősegítő alternatívák kidolgozására, amelyek egyelöre még nem kész és teljes csomagterveket, hanem a célok elérését biztosító akciókat, megoldási módokat tartalmazzák.

Itt előfordulhat, hogy a változtatást előkészítő csoport külső segítségre szorul. Ilyenkor bevonhatók a munkába olyan külső szakemberek, tanácsadók, akik több információval rendelkeznek bizonyos müszaki, gazdasági, piaci stb. kérdésekről.

Az ötödik fázis a változtatási döntések meghozatala. A szóba jöhető - reálisnak mutatkozó - akciók részletes kimunkálására (modellezésére) és komplex értékelésére egy következö lépésben (de még a tervezésen belül) kerül sor.

Ennél a munkánál az egyes alternatívákat ajánlatos a célrendszer paraméterei szerint leírni, és az előre felállított döntési kritériumok alapján, a megfelelő döntési módszer alkalmazásával a legkedvezőbb cselekvési változatot kiválasztani. A különféle lehetséges cselekvési változatokból végül is egyetlen, megvalósításra előkészített változtatási akciótervet kell kialakítani. 
A cselekvési változatok modellezését és a megvalósításra javasolt akcióváltozat kiválasztását követően kell átlépni a hatodik fázisba, mely a megvalósítás előkészítési szakasza. A gyakorlati megvalósítás első lépéseként a döntéshozónak határozni kell a megvalósítás módszeréről, mely lehet:

- gyors, általános bevezetés, átalakítás (áttörés) (pl. a közlekedési rendben történő változtatás);

- fokozatos bevezetés (pl. a számítógép alkalmazásakor először csak egyegy részterületen);

- kísérleti bevezetés (pl. egy marketingakció esetén) (Vezetés, 2009).

A változások kezelése az egyik legbonyolultabb feladat a vezető számára, a siker elérése érdekében a vezetőnek nem megoldásokra, hanem magára a folyamatra kell koncentrálnia. A dolgozóknak különböző munkákban kell jártasnak lenniük ahhoz, hogy új megoldásokat találhassanak, ennek következtében fontosabb a dolgozók képessége az új ismeretek elsajátításához, mint egy adott szakma ismerete (Vezetés, 2009).

A változások gyakran együtt járnak a konfliktusokkal, a dolgozók reagálása a változásokra, az ismeretlen dolgoktól való félelem és a folyamatosan változó gazdasági- és társadalmi helyzet következtében.

\section{KONFLIKTUSKEZELÉS}

A konfliktusok napjainkban minden szervezetben jelen vannak, ezért is fontos vizsgálnunk, hiszen a vezetési stílushoz és a változási készséghez hogyan kapcsolódik a konfliktuskezelés módja. A konfliktus számos okból kialakulhat, mely pozitívan és negatívan is befolyásolhatja a munkavégzés módját.

A konfliktus belső állapot, amelynek során a személyben a látszólagos vagy ténylegesen össze nem egyeztethető, ellentétes erők, motívumok egyidejüleg hatnak. A konstruktív konfliktusok a fejlödés mozgató rugói, amikor a konfliktus megoldása fejlődést eredményez. Azonban létezik destruktív konfliktus is, amely a legjobb szándék mellett is a kapcsolatok romlásához vezetnek (Balogh, 2000). A valóságban nem minden konfliktus baj, a konfliktusokat mindig adott helyzetben, adott összefüggésében kell megítélnünk. A konfliktus megoldása egyaránt jelenthet sikert és kudarcot, tehát ennek megfelelően kell foglalkoznunk vele a mindennapi és vezetői tevékenységben egyaránt (Zrinszky, 1985). 


\section{Konfliktusmegoldó stratégiák}

A vezető érdeke, vagy célja ütközhet a társak, a partner érdekével, véleményével, ami konfliktust (konfliktushelyzetet) eredményez. A vezetői lét velejárója a vita és a konfliktus. A konfliktushelyzetek azok a szituációk, amelyekben az emberek törekvései összeegyeztethetetleneknek tünnek.

A viselkedések alapján a konfliktusok kezelésének öt alapvető formáját különböztetjük meg:

1. Versengő - Vitatkozó: Az egyén saját szándékait érvényesíti a másik személy rovására bármely befolyásolási mód (meggyőzőképesség, rang, gazdasági szankció stb.) alkalmazásával azért, hogy jobb helyzetbe kerüljön. A versengés jelentheti a saját igazáért való kiállást, a helyesnek vélt álláspont védelmét vagy egyszerüen a győzelemre való törekvést (Poór, 2013; Mikulás, 1999).

2. Alkalmazkodás - Együttmüködés: Az egyén lemond a saját szándékáról, hogy a másik fél szándékai is érvényesülhessenek. Bizonyos önfeláldozás van ebben az eljárásban. Az alkalmazkodás öltheti az önzetlen nagyvonalúság vagy a jótékonyság formáját, de lehet a másiknak való kényszerü engedelmesség, illetve a másik szempontjainak, érveinek őszinte elfogadása is (Poór, 2013; Mikulás, 1999).

3. A közös megoldás keresése - Megállapodó: Magában rejti azt a törekvést, hogy együtt dolgozva a másik személlyel alakítsanak ki valamilyen megoldást, amely "teljesen" megfelel mindkét fél szándékainak. A közös megoldás keresése lehet pl. egy nézetkülönbség mélyebb feltárása azzal a céllal, hogy egymás megértése révén okuljanak a felek, vagy valamilyen feltétel megteremtésére való szövetség, amelynek hiánya versengésre késztetné a feleket (Poór, 2013; Mikulás, 1999).

4. Elkerülés - Tartózkodó: Az egyén nem követi közvetlenül sem saját, sem a másik fél szándékait. Az elkerülés lehet a diplomatikus kitérés, a kérdés kedvezőbb időpontra való halasztását, vagy egyszerűen visszahúzódást egy fenyegető helyzetből (Poór, 2013; Mikulás, 1999).

5. Kompromisszum keresés - Alkalmazkodó: A cél valamilyen kivitelezhető és kölcsönösen elfogadható megoldás találása, amely részlegesen mindkét felet kielégíti. Közvetlenül ragadja meg a kérdést (értelmezi a helyzetet), mint az elkerülő, de nem tárja fel olyan mélységig, mint a problémamegoldó. A kompromisszum keresése félúton való találkozás, kölcsönös engedményeket vagy egy gyors, áthidaló megoldás keresését jelenti (Poór, 2013; Mikulás, 1999). 


\section{EGY MULTINACIONÁLIS VÁLLALAT VEZETÖINEK VIZSGÁLATA}

Napjainkban a dinamikusan változó gazdasági környezet és a kiélezett versenyhelyzetben a vezetés fontos szerepet játszik egy vállalat estében. A vezetési stílusok, változási készségük és konfliktuskezelésük hatással van a vállalat sikerére.

Vizsgálatunkban ezért egy debreceni multinacionális vállalatot vezetőit vontuk be, azért mert a vállalat hosszú múltra tekint vissza, illetve a vezetés három szintjét lehet náluk elkülöníteni, mely árnyaltabb képet adhat számunkra, hogy az egyes szinteken milyen eltérések és hasonlóságok mutatkoznak a vezetési stílusban, a konfliktuskezelés módjában, illetve a változási készségben.

Vizsgálatunk alapját a vállalat egészét tekintve 89 vezető képezte, mind a vezetési stílus, változási készség, mind a konfliktuskezelés tekintetében. Ebből 12 fö felső vezető, 28 fő középvezető és 49 fő operatív vezető. A vezetés vizsgálata során három fajta kérdőívet használtunk fel. Az első kérdőív a vezetési stílust vizsgálta, mely segít behatárolni, jellemezni az egyes vezetők vezetési stílusát. A második kérdőív a változási készséget vizsgálta, hogy milyen gyorsan és milyen mélységben tudnak az egyes szinteken lévő vezetők alkalmazkodni az új helyzetekhez. A harmadik kérdőív a konfliktusok kezelését vizsgálta, azt hogy az vezetők milyen módszerrel oldják meg a vállalaton belül kialakult konfliktusokat. Az eredmények értékeléséhez leíró statisztikát alkalmaztunk

A kutatás célkitüzései:

- Megvizsgálni, hogy a különböző szintủ vezetők eltérő vezetési stílust alkalmaznak-e.

- Megvizsgálni, hogy a három szint vezetői milyen konfliktuskezelési módot alkalmaznak.

- Megvizsgálni, hogy a három vezetöi szint milyen mértékben tud alkalmazkodni a változásokhoz.

Vizsgált vezetői csoportok:

- Felsővezetők: A legfelső vezetést képezik. Magas döntési jogkörrel rendelkeznek. Anyagi döntési jogkörük összeghatárhoz van kötve.

- Középvezetők: Közvetlenül a felső szintű vezetés alatt helyezkednek el, a vezetés második szintjén. Döntési jogkörük magas, aláírási jogkörrel rendelkeznek. 
- Operatív vezetés: A vezetés harmadik szintjét a vállalatnál lévő csoportok vezetői képezik. Kisebb területek irányításáért felelősek, aláírási joguk nincs, döntési jogkör csak a saját területükön van. Anyagi, döntési jogkörrel nem rendelkeznek, függenek a feletteseiktöl.

\section{Vezetési stílus vizsgálata}

A vizsgálatunkhoz Hersey és Blanchard szituációs modelljét alkalmaztuk. A modellnek megfelelöen megvizsgáltuk, hogy a vállalat esetében az egyes vezetői szinteken milyen vezetési stílusok jellemzőek. A vizsgálat eszköze Mikulás Gábor (1999) Menedzsment címü könyvéből származó önkitöltős kérdőív volt, amely 12 kérdésből állt. Minden kérdés esetében 4 válaszlehetőséget sorakoztat fel, amelyek közül a vizsgált vezetőknek a rájuk leginkább jellemzőt kellett kiválasztaniuk.

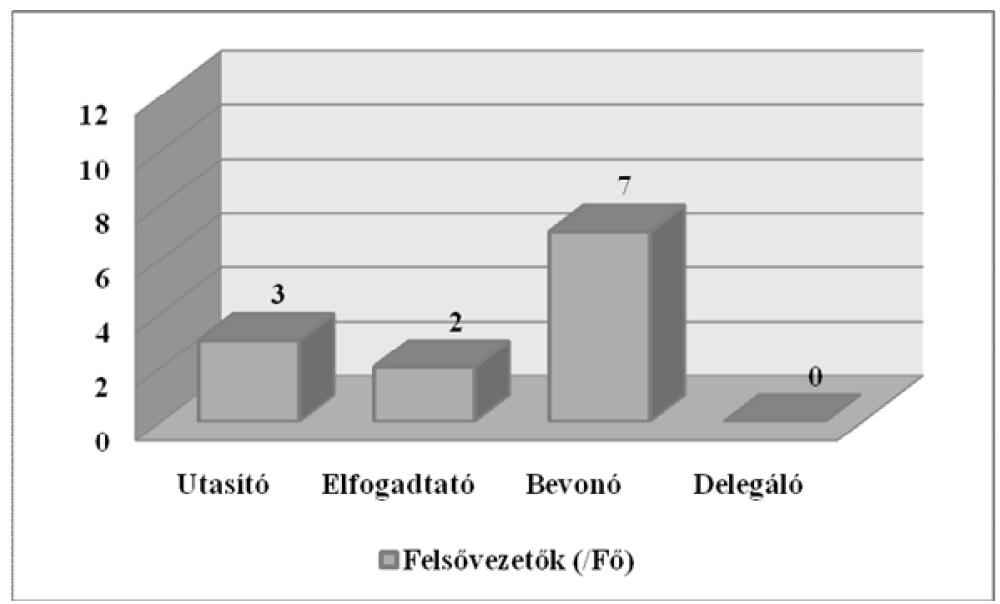

3. ábra: Felsővezetők vezetési stílusa

(Forrás: saját adatbázis alapján)

A felsővezetők stílusaira vonatkozó eredményeket a 3. ábra szemlélteti. Láthatjuk, hogy legmagasabb számban (7fö) a bevonó vezetési stílust alkalmazzák. Erre a vezetési stílusra jellemző, hogy a vezető a beosztottjait bevonja a munkába és a döntéshozatalba egyaránt. A felsővezetőkre azért jellemző ilyen magas arányban ez a fajta vezetési stílus, mert ők már régóta dolgoznak a vállalatnál, ugyanazzal a csoporttal, munkatársakkal végzik közösen a feladataikat, így kialakult az a fajta együttmüködés és bizalmi légkör a munkájuk során, amely magával vonja a bevonó vezetési stílust. Az ábra alapján látható, hogy a delegáló vezetési stílust a felsővezetők nem alkalmazzák a munkájuk során. A felső szin- 
tủ vezetésre jellemző az, hogy az egyes feladatokat delegálják a beosztottjaiknak, így önállóságot adva nekik. Az utasító és az elfogadtató vezetési stílus már magas számban (3 és 2 fö) jellemzi az egyes szintű vezetést. Ez a két vezetési stílus azokra a vezetőkre jellemző, akiknek újonnan érkezett, belépő, kezdő és tapasztalatlan dolgozókat kell irányítaniuk. A felső vezetésnek pedig általában már összeszokott, tapasztalt munkatársakkal kell együttmüködniük.

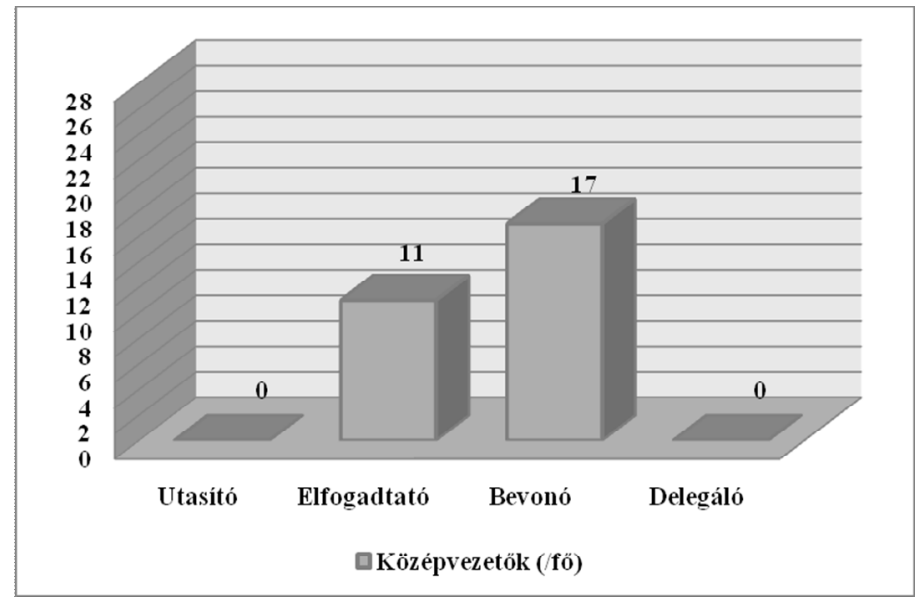

4. ábra: Középvezetők vezetési stílusa

(Forrás: saját adatbázis alapján)

A 4. ábrán láthatjuk a középvezetők által alkalmazott vezetési stílusokat. A legmagasabb számban (17 fö) a bevonó vezetési stílust alkalmazzák. Ezen a vezetési szinten pedig fontos, hogy a vezetö és a csoport közösen hozzanak döntéseket, a munkába és a döntéshozatalba mindenkit bevonjon a vezetö és így a munkatársak támogatva érezzék magukat. Ezeket pedig a bevonó vezetés segítségével tudja a vezető megvalósítani. Az elfogadtató vezetési stílus alkalmazása is magas értéket kapott (11 fö). Ezt a vezetési stílust jellemzően akkor alkalmazzák, amikor még kevéssé tapasztalt dolgozókkal kell együttmüködnie a vezetőnek. A középvezetők esetében pedig ez gyakran előfordul, hiszen munkakörükből adódóan folyamatosan változó összetételü csapatokat kell irányítaniuk. Az utasító és a delegáló vezetési stílus egyáltalán nem jellemző a középvezetőkre a vállalatnál. Az utasító vezetési stílusra az erős szabályozottság, ellenőrzések, míg a delegáló stílusra pedig a magas önállóság és szabadság a jellemző. A középvezetés viszont ezzel szemben olyan dolgozókat és munkacsoportokat irányít, ahol nem jellemző az, hogy a vezető magas önállósággal és szabadsággal ruházza fel az alkalmazottait. 


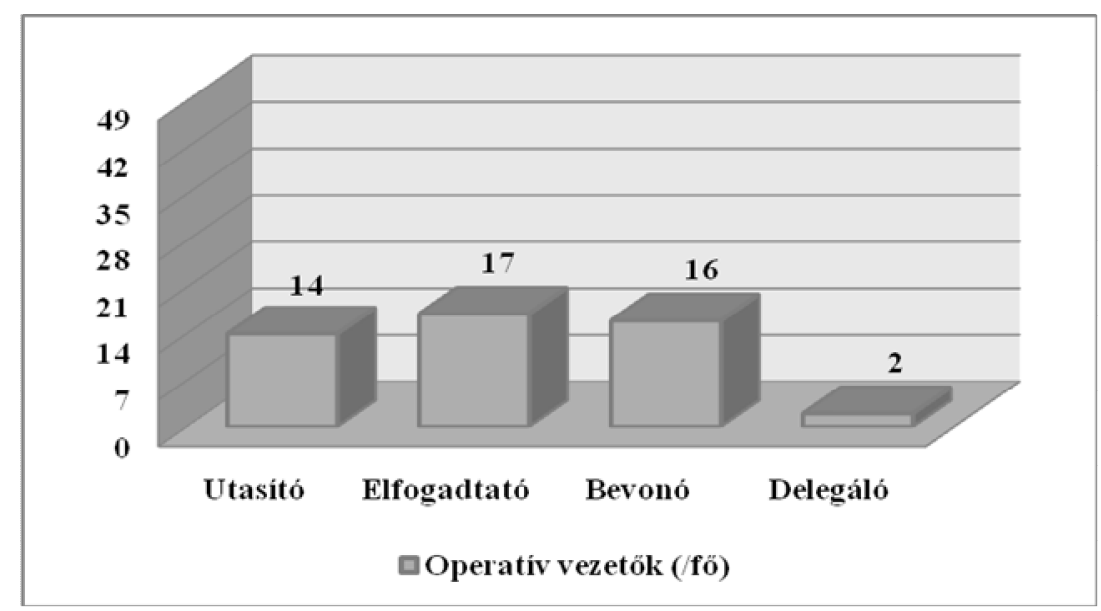

5.ábra: Operatív vezetők vezetési stílusa

(Forrás: saját adatbázis alapján)

Az 5. ábrán láthatjuk az operatív vezetésre jellemző vezetési stílusokat. Az operatív vezetők esetében a legmagasabb arányban az elfogadtató vezetési stílus alkalmazása a jellemző (17 fö). Erre a vezetési stílusra jellemző, hogy a vezető részletesen elmagyarázza a teendőket az alkalmazottaknak, hiszen ez a vezetési stílus a kevéssé tapasztalt dolgozók esetében alkalmazandó. A másik legjellemzőbb vezetési stílus az operatív vezetők esetében az utasító stílusú vezetés (14 fö). Ezt a vezetési stílust az újonnan érkező, belépő dolgozók esetében alkalmazza a vezetés. Ebből adódóan a vezetőt világos és egyértelmü utasítások és erősen szabályozó és ellenőrző funkció jellemzik. A bevonó vezetés is magas értéket kapott (16 fó). Ezt a vezetési stílust magasabb szinteken dolgozók vezetésekor alkalmazzák, ami nem jellemző az operatív vezetőkre. A delegáló stílusú vezetés kevéssé jellemző (2 fö). Ennek oka szintén az, hogy ezt a vezetési stílust már jól összeszokott csapatok esetében alkalmazzák, amelyek nem jellemzőek a cég esetében az operatív vezetésre. 


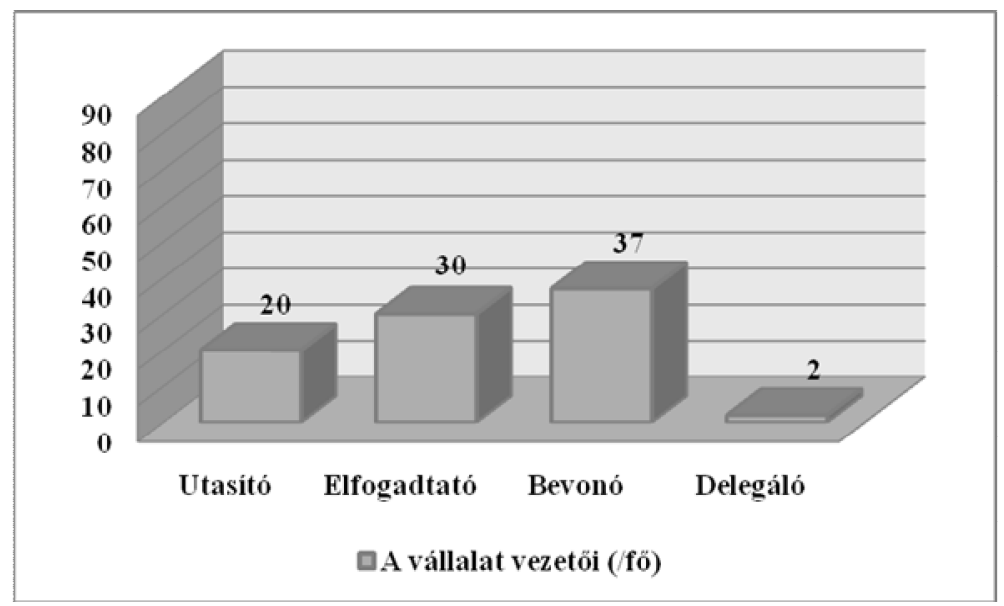

6. ábra: A vállalatra jellemző vezetési stílus (Forrás: saját adatbázis alapján)

Amint azt a 6. ábra is szemlélteti a vállalat vezetésére legmagasabb arányban a bevonó vezetés jellemző (37 fö). Ennek oka, hogy ezt a vezetési stílust általánosságban a középvezetők alkalmazzák, akik a legmagasabb arányban dolgoznak a vállalatnál a három vezetői szint közül. Az elfogadtató és az utasító vezetési stílus alkalmazása is magas értékeket kapott (30 és 20 fö), amely azzal magyarázható, hogy ezt a két vezetési stílust az operatív vezetők alkalmazzák, akik a középvezetőkhöz hasonlóan szintén magas arányban dolgoznak a vállalatnál. A delegáló stílusú vezetés 2 fö esetében jelenik meg, melyet a legkevesebb arányban jelen lévő felső vezetők alkalmaznak.

\section{Változási készség vizsgálata}

Napjainkban már a változás fontos szerepet kapott és az egyik legfontosabb sikertényező egy szervezetben. A változási készség egyik kiemelkedő jelentése, hogy milyen gyorsan és milyen mélységben tudunk alkalmazkodni az új helyzetekhez és ez mára egy igen fontos kulcstényezővé vált.

A változási készséget a vállalat vezető körében Mikulás Gábor (1999) Menedzsment címü könyvéből származó kérdőív segítségével vizsgáltuk. A kérdöívben különböző csoportokra bontva állításokat sorakoztat fel, amelyeket egy 5 fokozatú Likert-skálán kellett értékelniük a különböző szintű vezetőknek. A skálán az 1-es érték jelenti a soha, az 5-ös érték pedig a mindig kategóriákat. Az állításokat az alábbi szempontok szerint osztotta csoportokra: stratégia, struktúra, menedzsment stílus, közös értékek, a munkatársak tapasztalatai, készségei, szabályok és rendszerek. A kérdőív kiértékelésénél az adott válaszokat a Likert- 
skálán jelölt érték alapján pontszámokra váltottuk át. Az eredményeket tekintve minél magasabb az elért pontszám, annál sikeresebb a szervezet a változások tekintetében. A kérdőívben szereplő 31 kérdésre maximálisan 155 pont szerezhető és a 110-nél kevesebb eredmény arra utal, hogy a kategóriákhoz kapcsolódó bizonyos jellemzők, tulajdonságok közül több hiányzik az adott vezetői szinten.

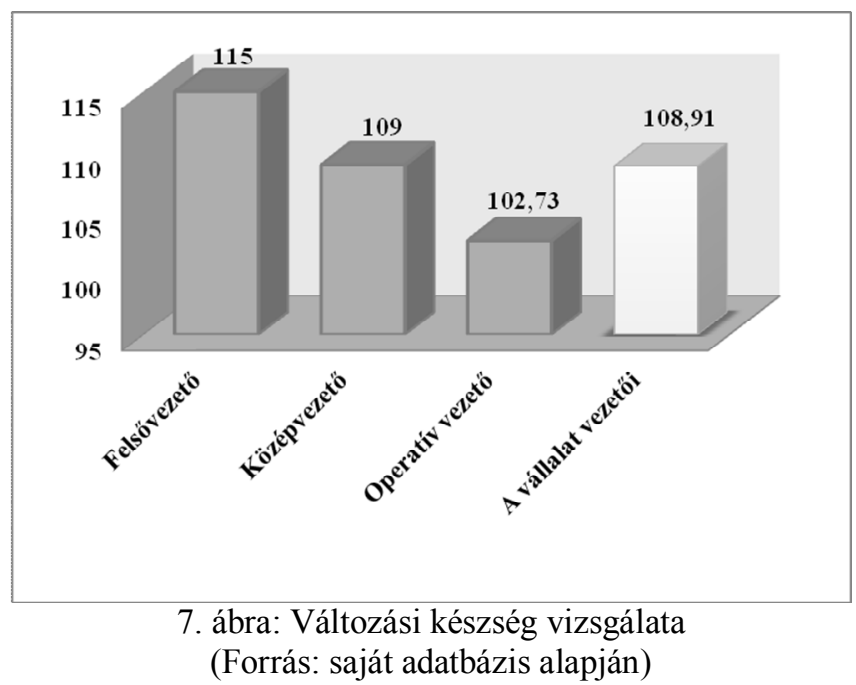

A 7. ábra alapján láthatjuk, hogy a legnagyobb hiányosságokkal az operatív vezetők rendelkeznek, melyet a 102,73-as átlagpontszám mutat. Összességében nézve a középvezetők 109 pontos értéke elfogadhatónak mondható. A felső vezetés 115-ös pontszáma megfelelő. A vállalat egészére vetítve az eredményeket a 108,91 -es érték elfogadható. A vállalat arra törekszik, hogy az összes vezetöi szint elérje a 110-es értéket. Átlagban minimális javítási potenciállal a 110-es érték gyorsan és hatékonyan elérhető.

\section{Konfliktuskezelés vizsgálata}

A vezetők konfliktuskezelési módjának vizsgálatához szintén kérdőívet használtunk (Mikulás, 1999). A kérdőívben állításpárokat sorakoztat fel, amelyek közül a teszt kitöltőjének a rá leginkább jellemzőt kellett kiválasztania. A teszt 30 megválaszolandó kérdésből áll. 


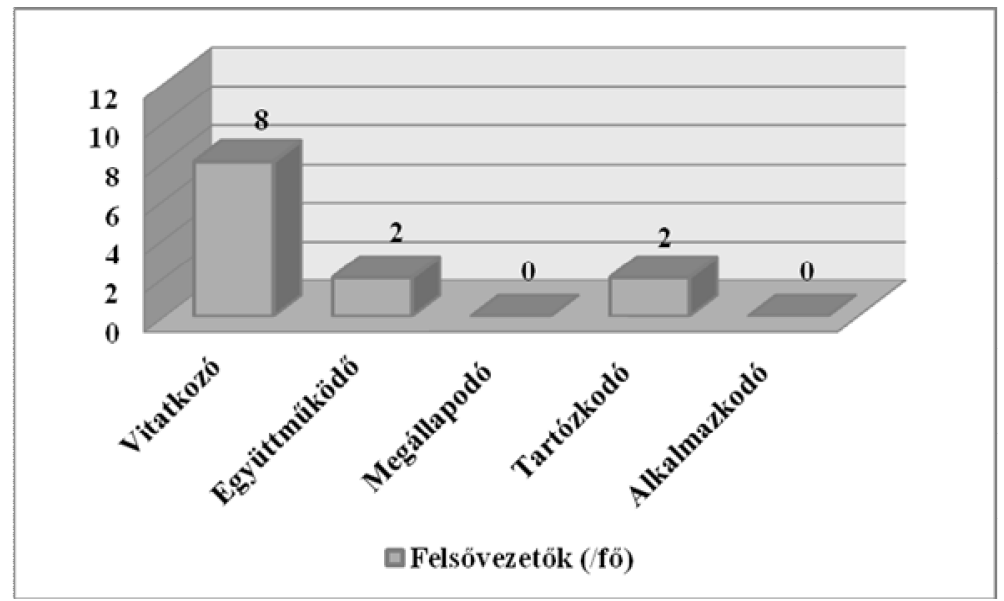

8. ábra: Felsővezetők konfliktuskezelési módja (Forrás: saját adatbázis alapján)

A 8. ábra alapján megállapítható, hogy a felső vezetés jelentős része a vitatkozó konfliktuskezelési módot részesíti előnyben (8fö). Ez azzal magyarázható, hogy a szervezet által képviselt értékek közé tartozik az, hogy a problémákat minél hatékonyabban tudják orvosolni. Ezt úgy érik el, hogy egy konfliktus felmerülése esetén az összes érintett fél véleményét, álláspontját kikérik és egyeztetik ezeket. A vezetők „megvitatják”, illetve „vitahelyzetet” teremtenek, hogy így jussanak el közösen a legkonstruktívabb megoldáshoz. Ez a fajta konfliktuskezelési mód szervesen hozzákapcsolódik a vállalati kultúrához, miszerint a dolgozók bevonása és véleményük értékelése által lehet igazán sikeres a szervezet.

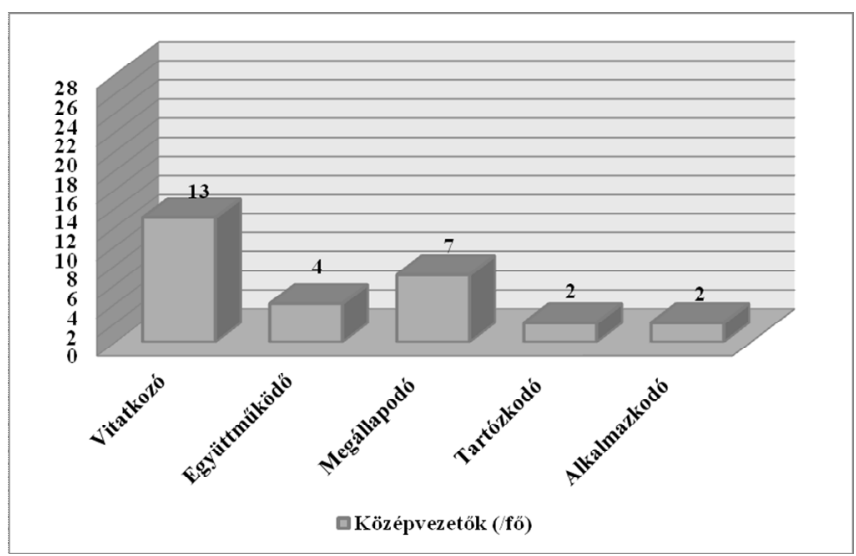

9. ábra: Középvezetők konfliktuskezelési módja

(Forrás: saját saját adatbázis alapján) 
A 9. ábrán láthajuk, hogy a középvezetők jelentős része, 13 fő a vitatkozó konfliktuskezelést alkalmazza, ami azt jelenti, hogy a felmerülő problémárkra a minél jobb és gyorsabb, célravezetőbb megoldást keresi. Az együttmüködő (4 fö) és a megállapodó stílus ( 7 fö) minimális számban a tartózkodó ( 2 fö) és az alkalmazkodó (2 fö) stílus is jelen van. A vitatkozó konfliktuskezelési módszer jó hatással lehet a szervezet egészére, hiszen elősegítheti a csoport céljainak elérését, bátorítja a kreativitást, motiválja az ötletek felszínre kerülését, a változást és az önértékelés szellemét viszi a csoportba.

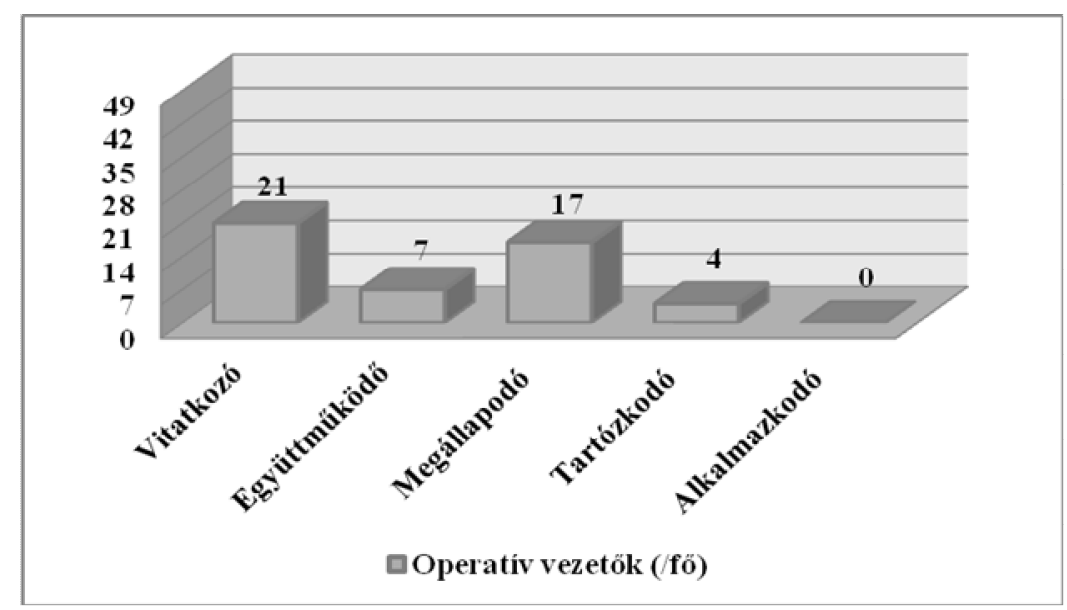

10. ábra: Operatív vezetők konfliktuskezelési módja (Forrás: saját adatbázis alapján)

A 10. ábrán láthatjuk, hogy az operatív vezetők esetében kiemelkedően magas értéket kapott a vitatkozó (21 fö) és a megállapodó (17fö) konfliktuskezelési mód. E mellett 7 főnél jelen van az együttmüködő és 4 fönél a tartózkodó stílus is. Ennek oka a vezetési stílusnál kapott eredményekhez hasonlóan az, hogy az operatív vezetők különböző szervezeti egységeket irányítanak illetve tartanak össze, amelyek különbözö konfliktuskezelési módokat kívánnak meg. Az alkalmazkodó konfliktuskezelési mód nem jellemző az operatív vezetőkre. 


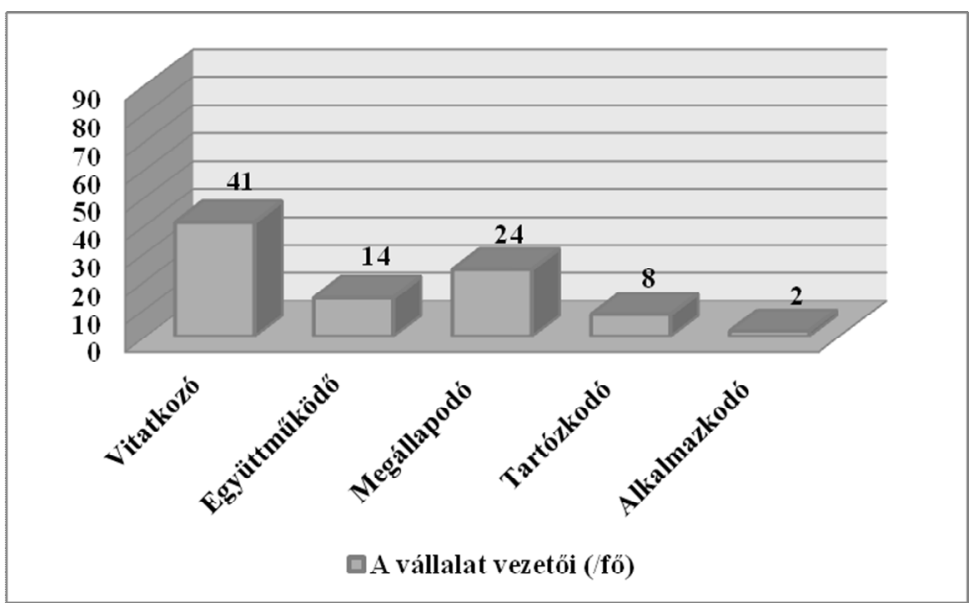

11.ábra: A vállalatra jellemző konfliktuskezelés (Forrás: saját adatbázis alapján)

Amint a 11. ábrán is láthatjuk, a vállalat vezetöire összességében a vitatkozó konfliktus kezelési mód jellemző (41 fö). E mellett magas értéket kapott a megállapodó (24 fö), az együttmüködő (14 fö), illetve a tartózkodó stílus (8fö). A cég filozófiájából fakad, hogy a konfliktuskezelés során az összes érintett fél véleményét, álláspontját kikérik. Ez által fejlesztik a szervezetet, hiszen elősegíthetik a célok elérését, serkentik a kerativitást, a motivációt és az önértékelés.

\section{KÖVETKEZTETÉSEK}

A kapott eredmények alapján következtetéseket és javaslatokat vonunk le és összefoglaltuk kutatási eredményeinket, melyeket tudományterületünkből adódóan külön fejeztben ismertetünk.

Kutatásunk során feltételeztük, hogy a felső, a közép és az operatív szintü vezetők azonos vezetési stílust alkalmaznak munkájuk során. A kapott eredmények alapján a három vezetői csoport részben alkalmazza ugyanazt a vezetői stílust, ugyanis a felső és a középvezetők a bevonó vezetést alkalmazzák, míg az operatív vezetők az elfogadtató és a bevonó vezetést egyaránt alkalmazzák. Ennek oka az, hogy a különböző munkacsoportok vezetői más és más szervezeti egységekben dolgozókat irányítanak. A különböző szervezeti egységek irányítása pedig különféle vezetöi stílust igényel.

A felső és középvezetők a bevonó vezetést alkalmazzák, ugyanis a sikeres müködéshez elengedhetetlen a dolgozók eredményes bevonása, amely a vezetés támogatása nélkül kudarcra van ítélve. 
Kutatásunk során vizsgáltuk, hogy a három szint vezetői milyen konfliktuskezelési módot alkalmaznak. A középvezetők, az operatív vezetők és a felsővezetők a vitatkozó konfliktuskezelési módot alkalmazzák munkájuk során, mert a rövid és hosszú távú célkitüzések eléréshez ők látják át a legjobban a szervezet hatékonyabbá tételét, annak érdekében, hogy az optimális eredményeket elérjék. A vezetőkben benne van a legjobbra törekvés, mely a konfliktuskezelés során is megnyilvánul, bár nem biztos, hogy ez a legjobb.

Megvizsgáltuk, hogy a három vezetői szint milyen mértékben tud alkalmazkodni a változásokhoz. Ez azonban csak részben teljesült. A hármas szintủ vezetők esetében azonban nagyon nagy hiányosságokat tárt fel a kutatás, ugyanis számos olyan tulajdonság fejlesztésre szorul, mely a hatékony munkavégzést segíti elő. A felső és a középvezetők a kapott értékek alapján jól tudnak alkalmazkodni a változásokhoz. Ez abból fakadhat, hogy a középvezetők és a felsővezetők módjuk és lehetőségük van külföldi tapasztalatok megszerzésére, ezért jobban tudnak alkalmazkodni a körülményekhez.

\section{JAVASLATOK}

A kapott eredmények tükrében számos lehetőség adódik a fejlesztésre. Javaslataink közé tartozik a vezetői készségfejlesztö tréningek tartása a vállalaton belül. A továbbképzések alkalmával lehetőség nyílna a vezetők számára, hogy vezetői csoportonként külön-külön, illetve az összes vezetői szint együttesen is megismerkedhessen a különféle vezető stílusokkal. Így minden stílusnak megismernék a pozitív és negatív oldalait, következményeit. Ezen ismeretek segítségével pedig lehetőségük nyílna egy olyan összetett vezetői stílus kialakítására, amely a vállalat által képviselt értékekhez illeszkedve a leghatékonyabb irányítást tenné lehetővé mind a felsővezetöi szinten, mind pedig az alsóbb vezetői szinteken egyaránt.

A konfliktuskezelési készségek fejlesztésére workshopok megszervezését javasolnánk a vállalat számára. A wokshopok alkalmával egy adott szakterület iránt érdeklődő emberek közös munkával valami újat - általában szellemi terméket - hoznak létre az adott témában. A workshop az adott témára létrehozott munkacsoportban zajlik és tevékenysége egy adott kérdés vagy probléma interaktív elemzésére és megoldási javaslatok kidolgozására irányul, többnyire kreatív technikák segítségével. Ilyen workshopok alkalmával a résztvevők megismerhetnék a konfliktusok létrejöttének mechanizmusait, ami által képesek lennének céltudatosan viselkedni konfliktushelyzetben és gyarapítani a konfliktusok feloldását szolgáló eszköztárukat. Illetve a vezetők a beosztottakkal együttmüködve szintén elsajátíthatnának új konfliktuskezelési technikákat. 
A változási készség javítása érdekében a különböző munkacsoportok vezetőinek további vizsgálataival, illetve nagyobb számú részvételi aránnyal megállapíthatóvá válna a hiányosságok pontos forrása, illetve ha nem, vezetői szintre vonatkoztatva történne a vizsgálat, hanem területre felosztva a probléma hatékony megvilágítása és felmérése nagyban növelné a hatékonyságot és hozzájárulna a megfelelő a javítási potenciál megtalálásához.

A hármas szintü vezetők változási készségének másik fejlesztési módja az lehetne, ha ők is el tudnának egy bizonyos időt tölteni az anyavállalatnál (külföldön), illetve orientációs képzéseken vennének részt és más emberekkel, nemzetiségekkel együtt dolgozva új ismeretekre és tapasztalatokra tegyenek/tennének szert.

Javaslataink közé tartozik továbbá a coaching tevékenység bevezetése a vállalatnál. A coach olyan személy, aki a különböző szinteken lévő vezetőknek segíti a munkáját. Általában a vezetők további fejlődése érdekében alkalmaznak coachot, hogy a munkafolyamatok együttes átbeszélése során felhívja a figyelmet az elhamarkodott következtetésekre, hibás viselkedésmódokra, feltárva azok hátterét, lehetőség szerint megszüntesse a kiváltó okokat. A coaching az alábbi területeken nyújthat segítséget: a megfelelö vezetési stílus megválasztása, a hatékony delegálás, munkamegosztás, a döntés-előkészítés, döntéshozás, konfliktuskezelés, kommunikációs zavarok elhárítása, motivációs problémák kezelése, irányítási problémák és stratégiai dilemmák esetén.

\section{ÖSSZEFOGLALÁS}

A kialakult gazdasági helyzet és a kiéleződött versenyhelyzet következtében a vezetés szerepe napjainkra felértékelődött. A vezető hozzáállásával, példamutatásával és a célokért való elkötelezettség révén járul hozzá a sikeres müködéshez.

Kutatásunk célja az volt, hogy megvizsgáljuk egy ma Magyarországon sikeresen müködő multinacionális cég esetében a vezetés milyen vezetői stílust alkalmaz a hatékony és eredményes munkavégzés érdekében. Emellett a külső környezet dinamikus változásai által jelentkező adaptációs kihívásra a vállalat vezetői hogyan reagálnak, azaz milyen a változási készségük. A kiélezett versenyhelyzet kapcsán a szervezetekben a konfliktus gyakori jelenség és ennek kezelése komoly próbatétel a legkiválóbb szakemberek számára is.

Kutatásunk célja az volt, hogy a cégen belül a vezetés három szintjének vezetési stílusát, változási készségét és konfliktuskezelési módját megvizsgáljuk. Kutatásunk során számos célt tüztünk ki, melyeket leíró statisztika segítségével vizsgáltunk meg.

A vezetési stílus tekintetében a felső és középvezetők ugyanazt a stílust, a bevonó vezetést alkalmazzák, míg az operatív vezetők az elfogadtató és az utasí- 
tó stílust is alkalmazzák munkájuk során. A részvétre épülő vezetési stílus a vállalat számára a legelőnyösebb, mert a csoportmunkát, a fejlesztések támogatását, a rugalmasságot, az iránymutatást és a célkitüzést helyezik előtérbe. Az alkalmazott vezetési stílus függ az irányított dolgozóktól is. A felső vezetésnek nincs szüksége az utasító stílusra, hiszen ők már összeszokott munkacsoportokkal dolgoznak. Az operatív vezetők esetében viszont a bevonó vezetés nem alkalmazható, ugyanis ők kezdő, kevéssé tapasztalt dolgozókat irányítanak.

A kapott eredmények alapján megállapíthatjuk, hogy a feltételezésünk, miszerint a változási készség tekintetében minden vezetési stílus ugyanolyan mértékben képes alkalmazkodni, csak részben teljesült. Az operatív vezetők ennél a készségnél hátrányban vannak a többi szinthez képest, amit a vállalatnak orvosolnia kell.

Konfliktuskezelés tekintetében a vállalat vezetői a vitatkozó kategóriába tartoznak. Ez azzal magyarázható, hogy a vezetők a legjobbra törekednek, annak érdekében, hogy a szervezet minél eredményesebben és hatékonyabban müködhessen.

\section{Irodalomjegyzék}

1. Bakacsi Gyula. (2004): Szervezeti magatartás és vezetés Aula Kiadó Kft. Budapesti CORVINUS Egyetem (ISBN 963958549 1)

2. Balogh Éva (2000): Pszichológiai kislexikon, Tóth Könyvkereskedés és Kiadó Kft., Debrecen, 188.p

3. FN24, (2011) Helyzetfüggő vezetési stílusok: http://fn.hir24.hu/karrier/2007/09/28/helyzettol_fuggo_vezetesi_stilusok (letöltve: 2013.10.05 20:22)

4. Ford, R. C. - Fottler, M. D. (1995): Empowerment: A matter of degree. Academy of Managerment Executive, 21-32. p.

5. Gyökér I. (2006): Szervezeti viselkedés (oktatási segédanyag, Budapesti Müszaki Egyetem), Budapest

6. Karácsonyi András (2006): A leadership, a szervezeti kultúra és kapcsolatuk jellegzetességei a magyar szervezetek esetében, $9 \mathrm{p}$.

7. Mikulás Gábor (1999): Menedzsment, Szabolcs - Szatmár - Bereg Megyei Könyvtárak Egyesülés Nyíregyháza (1999), (ISBN:963 037288 6)

8. Poór F. (2013), Legyünk ,jóban” a konfliktussal, http://www.hrportal.hu/hr/legyunk-joban-a-konfliktusokkal-20130823.html (letöltve: 2013.11.08 19:33) 
9. Vezetés-vezetők honlap - szerző nélkül (2009): A változások vezetése (menedzselése).

http://www.vezetes-vezetok.hu/index.php/valtozasok-vezetese.html (letöltve: 2013.10.16. 19:40)

10. Zrinszky László (1985): Íratlan szabályok, Kossuth Könyvkiadó, Budapest, 117-126. p

Sipos Gábor: müszaki menedzser szakos (BSc) hallgató

Debreceni Egyetem Müszaki Kar Müszaki Menedzsment és Vállalkozási Tanszék, 4028 Debrecen, Ótemető u. 2-4.

Szücs Edit: főiskolai tanár

Debreceni Egyetem Müszaki Kar Müszaki Menedzsment és Vállalkozási Tanszék, 4028 Debrecen, Ótemető u. 2-4.

Takács Tímea: müszaki menedzser szakos (MSc) hallgató

Debreceni Egyetem Müszaki Kar Müszaki Menedzsment és Vállalkozási Tanszék, 4028 Debrecen, Ótemető u. 2-4.

Matkó Andrea: föiskolai adjunktus

Debreceni Egyetem Müszaki Kar Müszaki Menedzsment és Vállalkozási Tanszék, 4028 Debrecen, Ótemető u. 2-4. 
